University of Wollongong

Research Online

Faculty of Business - Papers (Archive)

Faculty of Business and Law

$1-1-2015$

Public perceptions of future threats to humanity and different societal responses: a cross-national study

Melanie J. Randle

University of Wollongong, mrandle@uow.edu.au

Richard Eckersley

Australia21 Ltd

Follow this and additional works at: https://ro.uow.edu.au/buspapers

Part of the Business Commons

Research Online is the open access institutional repository for the University of Wollongong. For further information contact the UOW Library: research-pubs@uow.edu.au 


\title{
Public perceptions of future threats to humanity and different societal responses: a cross-national study
}

\begin{abstract}
There is growing scientific evidence that humanity faces a number of threats that jeopardize its future. Public perceptions of these threats, both their risks and reactions to them, are important in determining how humanity confronts and addresses the threats. This study investigated the perceived probability of threats to humanity and different responses to them (nihilism, fundamentalism and activism), in four Western nations: the US, UK, Canada and Australia. Overall, a majority (54\%) rated the risk of our way of life ending within the next 100 years at $50 \%$ or greater, and a quarter $(24 \%)$ rated the risk of humans being wiped out at $50 \%$ or greater. The responses were relatively uniform across countries, age groups, gender and education level, although statistically significant differences exist. Almost $80 \%$ agreed "we need to transform our worldview and way of life if we are to create a better future for the world" (activism). About a half agreed that "the world's future looks grim so we have to focus on looking after ourselves and those we love" (nihilism), and over a third that "we are facing a final conflict between good and evil in the world" (fundamentalism). The findings offer insight into the willingness of humanity to respond to the challenges identified by scientists and warrant increased consideration in scientific and political debate.
\end{abstract}

\section{Keywords}

responses, threats, national, future, study, perceptions, societal, public, cross, different, humanity

\section{Disciplines}

Business

\section{Publication Details}

Randle, M. J. \& Eckersley, R. (2015). Public perceptions of future threats to humanity and different societal responses: a cross-national study. Futures, 72 4-16. 


\title{
Public perceptions of future threats to humanity and different societal responses: A cross-national study
}

\author{
Melanie Randle ${ }^{\mathrm{a}^{*}}$, Richard Eckersley ${ }^{\mathrm{b}}$
}

${ }^{a}$ School of Management, Operations and Marketing, Australian Health Services Research Institute, Faculty of Business, University of Wollongong, Northfields Ave Wollongong NSW 2500 Australia. mrandle@uow.edu.au.

${ }^{\text {b} A u s t r a l i a 21 ~ L t d, ~} 23$ Garland Rd, Bundanoon NSW 2578 Australia. richard@richardeckersley.com.au

*Corresponding author

\begin{abstract}
There is growing scientific evidence that humanity faces a number of threats that jeopardize its future. Public perceptions of these threats, both their risks and reactions to them, are important in determining how humanity confronts and addresses the threats. This study investigated the perceived probability of threats to humanity and different responses to them (nihilism, fundamentalism and activism), in four Western nations: the US, UK, Canada and Australia. Overall, a majority (54\%) rated the risk of our way of life ending within the next 100 years at $50 \%$ or greater, and a quarter $(24 \%$ ) rated the risk of humans being wiped out at $50 \%$ or greater. The responses were relatively uniform across countries, age groups, gender and education level, although statistically significant differences exist.

Almost $80 \%$ agreed "we need to transform our worldview and way of life if we are to create a better future for the world" (activism). About a half agreed that "the world's future looks grim so we have to focus on looking after ourselves and those we love" (nihilism), and over a third that "we are facing a final conflict between good and evil in the world" (fundamentalism). The findings offer insight into the willingness of humanity to respond to the challenges identified by scientists and warrant increased consideration in scientific and political debate.
\end{abstract}

\section{Keywords}

Global futures, human extinction, catastrophic threats, public perceptions 


\section{Introduction}

Scientific evidence and concern are mounting that humanity faces a defining moment in history, a time when we must address growing adversities, or suffer grave consequences. Reputable journals are canvassing the possibilities, including special issues of Scientific American (The end, 2010) and Futures (Human extinction, 2009). Most focus today is on climate change and its many, potentially catastrophic, impacts; other threats include depletion and degradation of natural resources and ecosystems; continuing world population growth; disease pandemics; global economic collapse; nuclear and biological war and terrorism; and runaway technological change (Dator, 2009; Tonn \& MacGregor, 2009; Hamilton, 2010; Halal \& Marien, 2011; Ehrlich \& Ehrlich, 2013). Threats not linked to human activities are a supervolcanic eruption and an asteroid collision (Tonn \& MacGregor, 2009).

Many of these threats are not new; scientists and other experts have warned of the dangers for decades. Nevertheless, the evidence is growing stronger, especially about climate change, and never before have their possible impacts been so powerfully reinforced by actual events, including natural disasters and calamities, and their sustained and graphic media coverage. Not surprisingly, surveys reveal widespread public pessimism about the future of the world, at least in Western countries, including a common perception of declining quality of life, or that future generations will be worse off (Eckersley, 2005; Eckersley, Cahill \& Wierenga, 2007; Eckersley, 2013). However, there appears to have been little recent research into people's perceptions of how dire humanity's predicament is, including the risk of the collapse of civilization, or human extinction. These perceptions have a significant bearing on how societies, and humanity as a whole, will deal with potentially catastrophic futures.

One such study is a 2004 international web survey, which found $45 \%$ of 600 respondents believed humans would become extinct (Tonn, 2009). However, the timeframe here was long: many felt this would happen within 500-1,000 years, and some in 5,000 years or more.

A 2005 survey of 1,000 Australians asked which of two scenarios of the world in the $21^{\text {st }}$ century more closely reflected their view (Eckersley et al., 2007):

"By continuing on its current path of economic and technological development, humanity will overcome the obstacles it faces and enter a new age of peace and prosperity."

"More people, environmental destruction, new diseases and ethnic and regional conflicts mean the world is heading for a bad time of crisis and trouble."

Two thirds of respondents (66\%) chose the pessimistic scenario, less than a quarter (23\%) the optimistic scenario. Compared to an earlier survey in 1995, pessimism had increased (Eckersley et al., 2007).

A 2011 study on "the Global Megacrisis" includes a bibliography and proposes four scenarios for how humanity deals with the multiple and interconnected threats posed by climate change and other critical issues (Halal \& Marien, 2011). Sixty “smart and thoughtful people” rated the relative probabilities of each scenario: 
Decline to disaster: World fails to react. More global warming, widespread energy and water shortages, economic depression, conflict, etc. Loss of civilization in many parts of the world ( $25 \%$ average probability).

Muddling down: World reacts partially, but problems continue to outdistance policies and technologies, ecological damage continues, increased poverty and conflict (35\%).

Muddling up: World reacts out of need and the help of information technology/artificial intelligence. Policies and technologies gain on problems. Disaster avoided but some disorder and disappointment (28\%).

Rise to maturity: Ideal transition to a humane and responsible global order (12\%).

How people react to the possibility of catastrophic futures (as distinct from their perception of their likelihood) will also shape how effectively humanity deals with the grave dangers. People can respond in very different ways to the same perception of threat, including apocalyptic suspicions about the 21st century (Eckersley, 2007; 2008). The responses include: nihilism (the loss of belief in a social or moral order; decadence rules), fundamentalism (the retreat to certain belief; dogma rules), and activism (the transformation of belief; hope rules). The categories make sharp distinctions between responses to highlight their differences and significance. In reality, the categories are fuzzy, reflecting tendencies or deviations from the norm, with subtle to extreme expressions. They are not mutually exclusive responses, but can overlap, co-exist and change over time in individuals and groups.

This study investigated the perceived probability of future threats to humanity, specifically whether "our existing way of life will end", and whether "humans will be wiped out", within the next 100 years. It also examined the level of agreement with three pairs of statements reflecting strong and weak nihilistic, fundamentalist and activist responses (while fundamentalism includes secular forms such as neoliberalism or market fundamentalism, the statements focused on religious fundamentalism). The study also assessed the association between global fears and levels of personal concern with a range of global or societal and personal issues (these concerns will be considered in depth in a separate paper). The questions comprised one part of a large survey of representative samples, totalling 2,073 people, in the US, UK, Canada, and Australia. A detailed explanation of the data collection procedure and measures is included in the supplementary material, which also has a description of the sample characteristics (Table A1).

\section{Methodology}

\subsection{Sample}

Individuals qualified to participate in the study if they were 18 years or over and a citizen or permanent resident of the US, UK, Canada or Australia. Quotas were imposed to ensure samples for each country were nationally representative for age, sex and region of residence. The total sample size was 2,073. Appendix 1 details the sample characteristics in terms of sex, age, education, employment status, employment position, relationship status and children. 


\subsection{Data collection}

Data was collected in January-February 2013 via online research panel company Survey Sampling International (SSI). The invitation to participate was sent to a nationally representative sample in each country and was available online until the minimum number of 500 responses for each country was achieved (15 days). Panel members received rewards in the form of points for completing the questionnaire which could be redeemed at a later date. The questions regarding global concerns, which form the basis of this study, were part of a larger questionnaire that covered a range of topics of general interest. The total questionnaire took approximately 35-40 min to complete.

\subsection{Measures}

Questions used to measure key constructs are described below. Actual measures are included as Appendix 2.

\subsubsection{Probability of threats to humanity}

Participants were asked: "In your opinion, how likely is it that our existing way of life will end in the next 100 years?" and "In your opinion, how likely is it that humans will be wiped out in the next 100 years?”. Answer options were presented on an 11-point Juster scale (Juster, 1966) from $0=$ "No chance, almost no chance" to 10 = "Certain, practically certain (99 in 100)".

\subsubsection{Beliefs about, and response to, the future}

The items used to measure beliefs about the future and our response to them were those proposed by Eckersley, based on his work (Eckersley, 2007; 2008). Participants were given the following instructions: "Thinking about global events and the future of the world, please indicate how much you agree or disagree with the following statements". They were then presented with six items which were developed to represent strong and weak expressions of nihilism, fundamentalism and activism (Appendix 2). Items were randomly ordered and all required an answer before the respondent could move on to the next question (they were not asked to choose between them).

\subsubsection{Global concerns}

Participants were asked: "In your everyday life, how concerned do you feel about the following issues?”. They were then presented with 23 items which were developed to represent the range of currently relevant global concerns including ecological, political, economic, technological, humanitarian/health and social/moral issues (Appendix 2). Items were randomly ordered and all required an answer before the respondent could move on to the next question.

\subsubsection{Personal concerns}

Participants were asked "Thinking about your own personal future, how concerned are you about each of the following?” They were then presented with a list of 19 items which was initially 
based on some of the future concerns identified by Lindfors et al. in their study of Finnish youth (Lindfors, Solantaus \& Rimpela, 2012). It was develop and extended to include a range of different types of issues relating to family/relationships, health/ageing, work/education, finance and emotional health (Appendix 2). Items were randomly ordered and all required an answer before the respondent could move on to the next question.

\subsubsection{Perceived stress}

The Perceived Stress Scale developed by Cohen was used to measure participants' self-reported level of stress (Cohen, Kamarck \& Mermelstein, 1983). Participants were presented with 14 items and asked to indicate how often they felt or thought a certain way in the past month. For example, in the last month how often have you "been upset because of something that happened?", "felt that you were on top of things?” and "found that you could not cope with all the things that you had to do?”. Participants were required to give answers for all items (some of which were reverse scored; indicated with an (R) in Appendix 2). Items were presented in random order and scores for all were summed to produce an overall score of perceived stress for each individual (range 0-56).

\subsection{Data analysis}

Correlation analysis was used to identify the direction and strength of associations between variables. Chi-square tests were performed to test for significant differences between groups for nominal and ordinal variables. One-way analysis of variance (ANOVA) was performed to test for significant differences between groups for metric variables. Results are reported at the $95 \%$ level ( $p \leq 0.05$ indicated by and asterisk, $\left.{ }^{*}\right)$ and $99 \%$ level ( $p \leq 0.01$ indicated by two asterisks, $\left.{ }^{* *}\right)$.

\section{Results}

\subsection{Probability of threats to humanity}

The percentages of participants who believe there is a $50 \%$ chance or greater that (1) our existing way of life will end and (2) humans will be wiped out are presented by country at Fig. 1 and by age group at Fig. 2 (note: common generational labels have been used for age groupings, however differences could reflect age and/or cohort characteristics).

Over a half of people (54\%) believe there is a $50 \%$ or greater chance of our way of life ending (mean score of 4.73 on an 11-point scale of $0-10$, or a $47 \%$ chance it will happen), and a quarter (24\%) believe there is a $50 \%$ or greater chance that humanity will be wiped out (mean score 2.47 , or a $25 \%$ chance it will happen). Almost three quarters (73\%) believe there is a $30 \%$ or greater risk of our way of life ending; $30 \%$ that the risk is $70 \%$ or more. Almost four in ten (39\%) believe there is a $30 \%$ or greater danger of humanity being wiped out, $10 \%$ that the danger is $70 \%$ or more. Opinions were similar across countries and age groups, however, statistically significant differences were found in perceived risk that humanity will be wiped out, with higher concern in the US than in the UK (Fig. 1), and higher in the youngest age group than in the oldest (Fig. 2). Few differences were found when other socio-demographic groupings were 
compared. For example, women were slightly less concerned than men that humans would be wiped out. No significant differences were found on other socio-demographic characteristics such as level of education.

Fig. 1: Proportion believing there is a $50 \%$ or greater chance of our way of life ending and humans being wiped out, by country

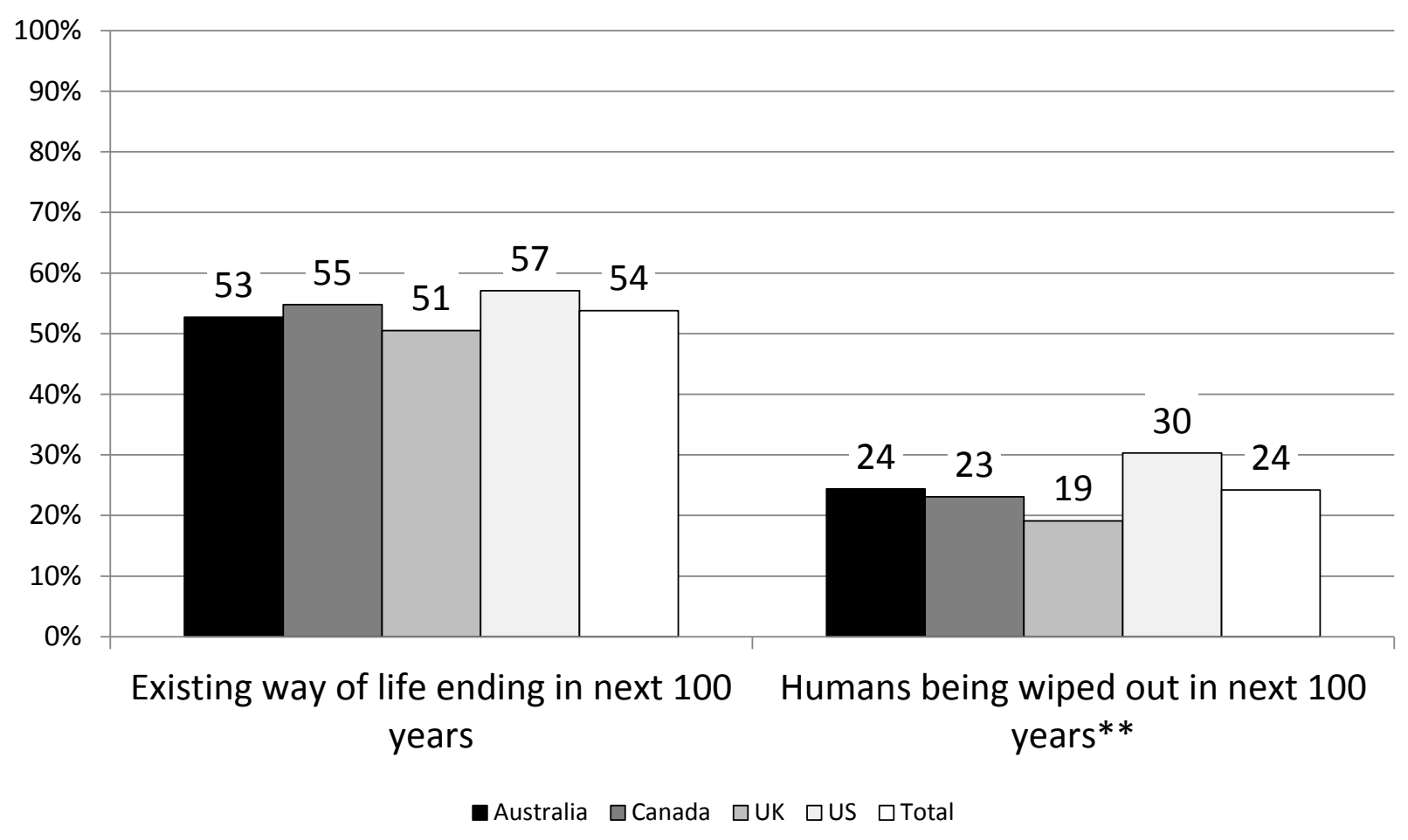


Fig. 2: Proportion believing there is a $\mathbf{5 0 \%}$ or greater chance of our way of life ending and humans being wiped out, by generation

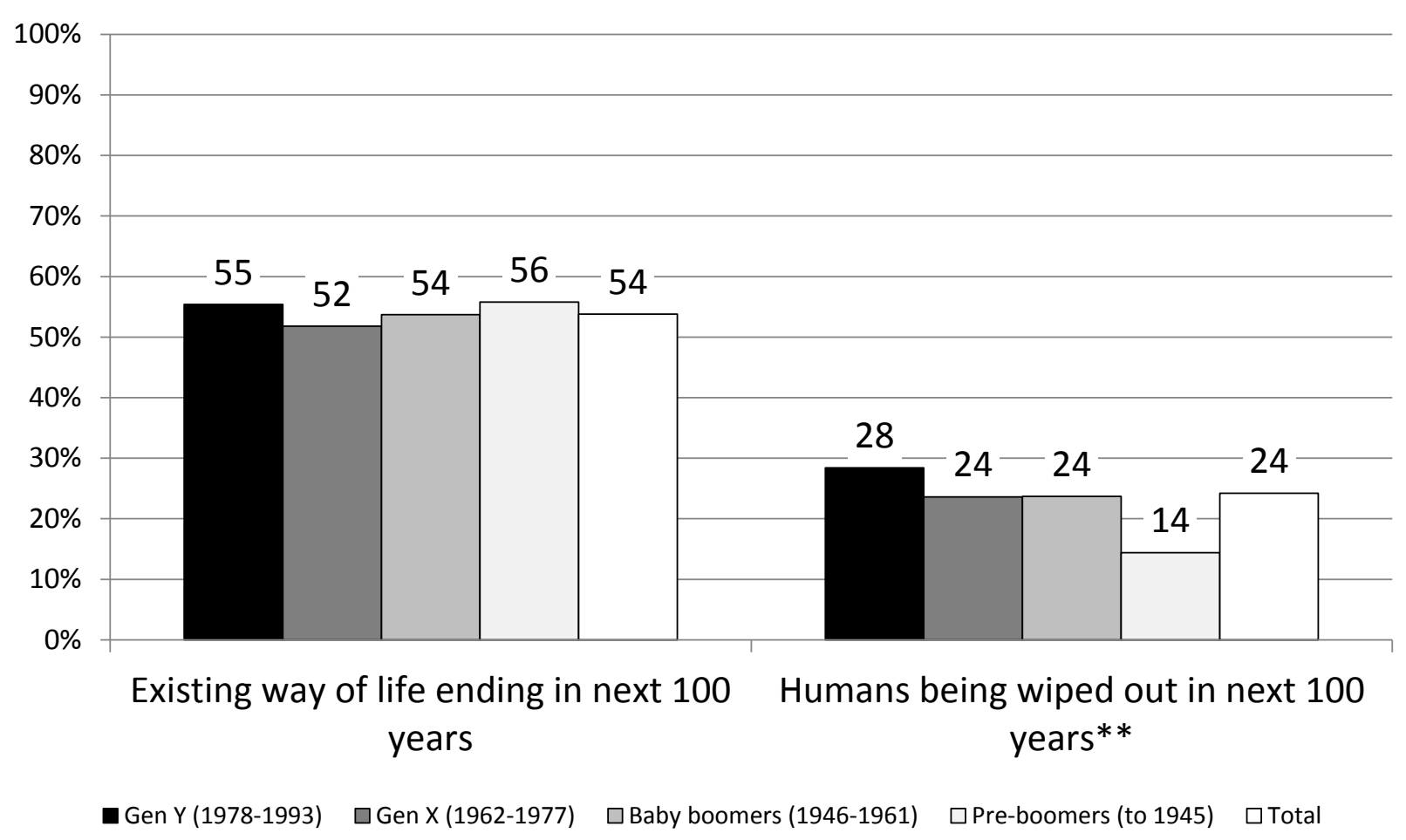

\subsection{Beliefs about, and response to, the future}

Participants were presented with six statements reflecting strong and weak nihilist, fundamentalist and activist responses to the future, drawing on the analysis cited above (Eckersley, 2007; 2008). The statements were:

\section{Nihilism}

- Strong: the world's future looks grim so we have to focus on looking after ourselves and those we love.

- Weak: we should enjoy the life we have now, and not worry about what might happen to the world in the future.

\section{Fundamentalism}

- Strong: we are facing a final conflict between good and evil in the world.

- Weak: we need to return to traditional religious teachings and values to solve global problems and challenges. Activism

- Strong: we need to transform our worldview and way of life if we are to create a better future for the world.

- Weak: hope for the future rests with a growing global movement that wants to create a more peaceful, fair and sustainable world. 
The highest level of agreement (indicated by the percentage of people who answered "agree" or "strongly agree" with the statement) was with the two "activism" responses: 78\% (strong) and $68 \%$ (weak). Agreement with strong fundamentalism was $36 \%$, weak fundamentalism $35 \%$, strong nihilism $48 \%$, and weak nihilism $34 \%$ (details are provided in the detailed tables at Appendix 3).

Figs. 3 and 4 shows levels of total agreement with the six different responses to the future by perceived probability of future threats to humanity (those who rate the chances of each as less than $50 \%$ versus those who rate the chances as $50 \%$ or greater). Significant differences were found at the $99 \%$ confidence level in agreement with strong and weak fundamentalism and nihilism statements between those who rated the risks to humanity higher versus lower. Significant differences at the $95 \%$ level were also found between agreement with activism responses for those who rated the risk of our way of life ending as higher and lower (Fig. 3), however this was not the case for those who rate the risk of humans being wiped out as higher and lower (Fig. 4).

Fig. 3: Agreement with response to the future by likelihood of our way of life ending - total sample

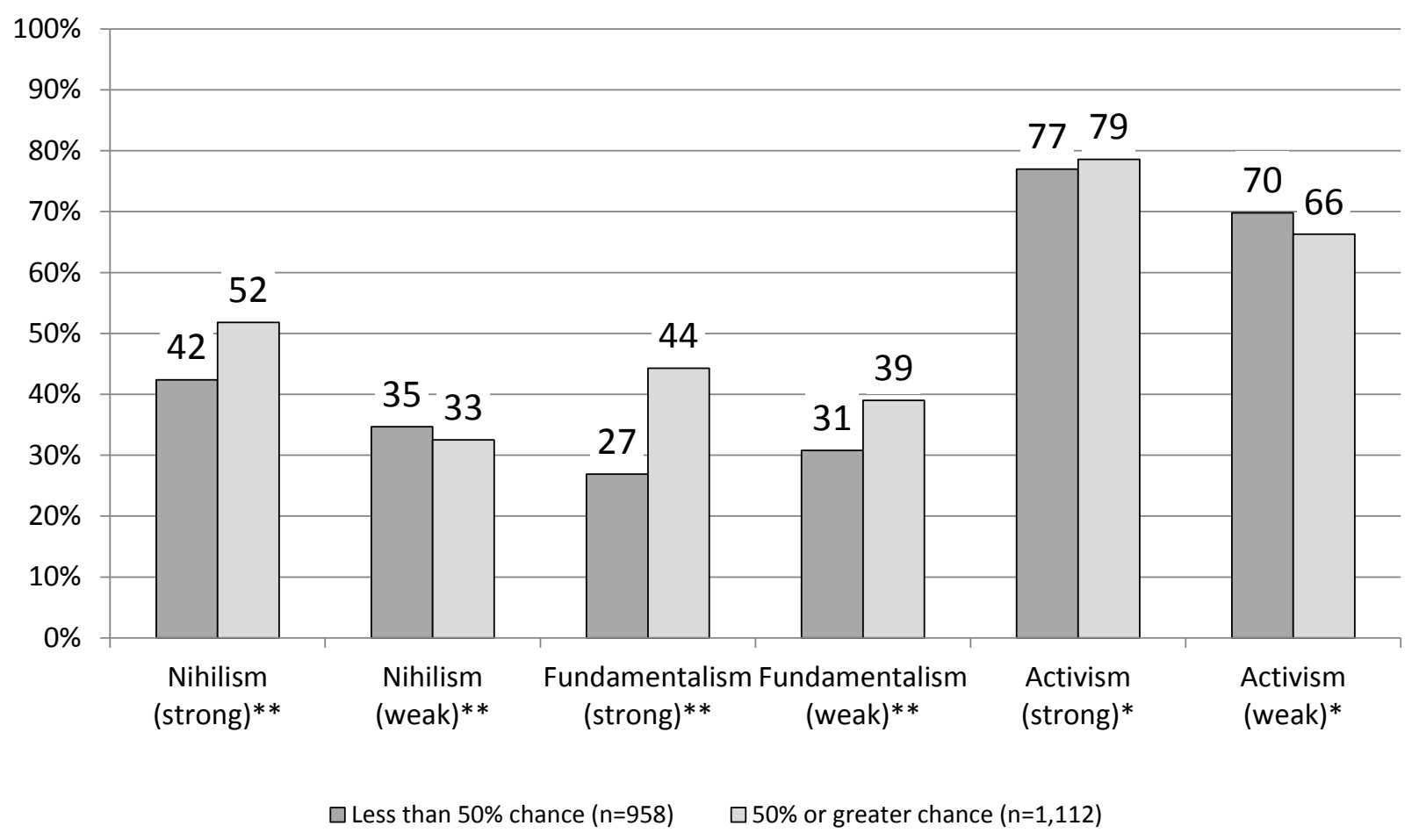


Fig. 4: Agreement with response to the future by likelihood of humans being wiped out total sample

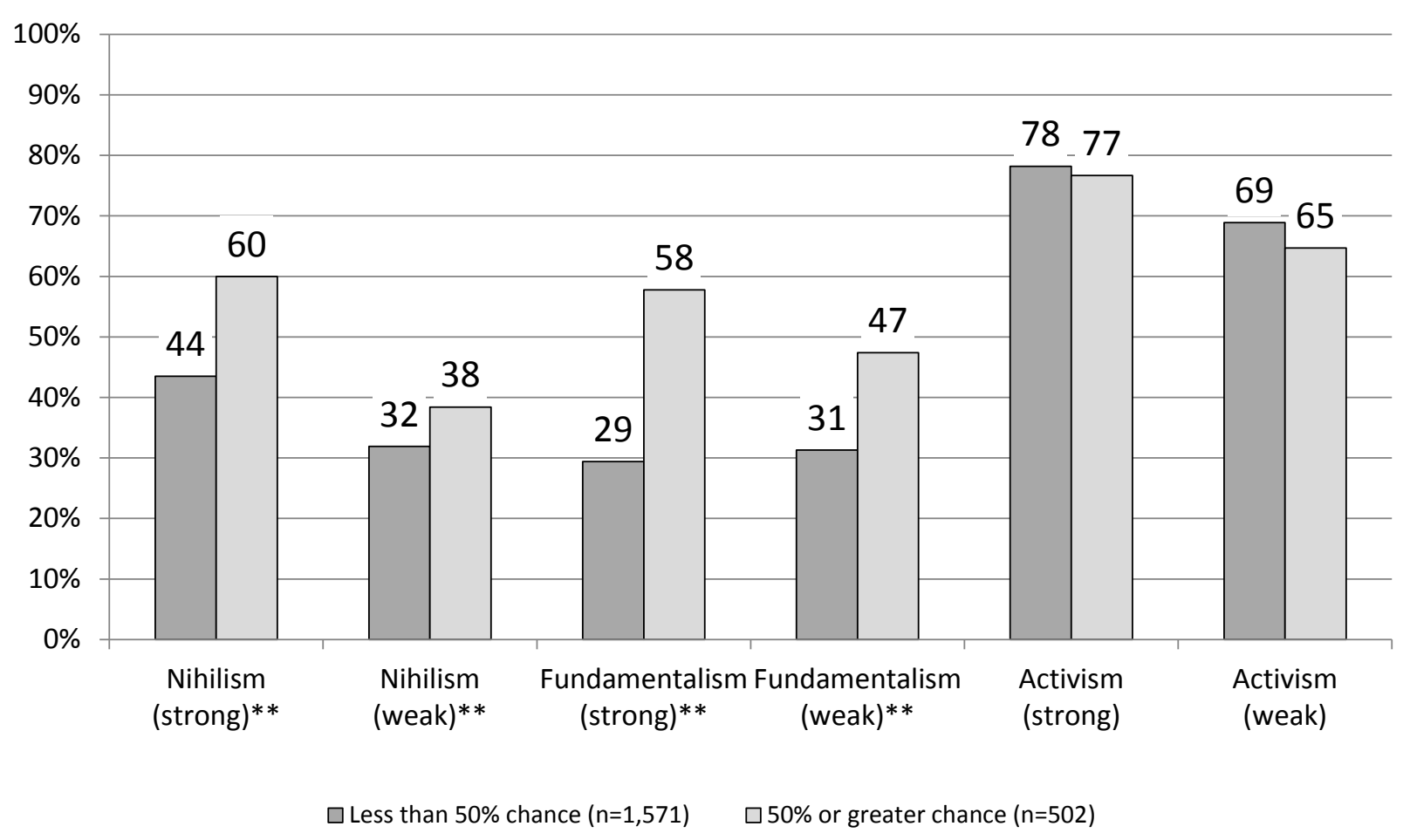

Figs. 5 and 6 show the percentage of the population that agrees with each response to the future, split by country (Fig. 5) and generation (Fig. 6). The US scored significantly higher agreement than the other three nations on both fundamentalism options, while Canada rated especially high on weak activism. Nihilism tends to fall with age, and fundamentalism (and weak activism) to rise with age. Responses to each pair of statements were positively correlated with each other for both fundamentalism and activism, but not nihilism (suggesting weak nihilism is capturing more than nihilistic inclinations). 
Fig. 5: Percentage of population either agreeing or strongly agreeing with each response to the future, by country

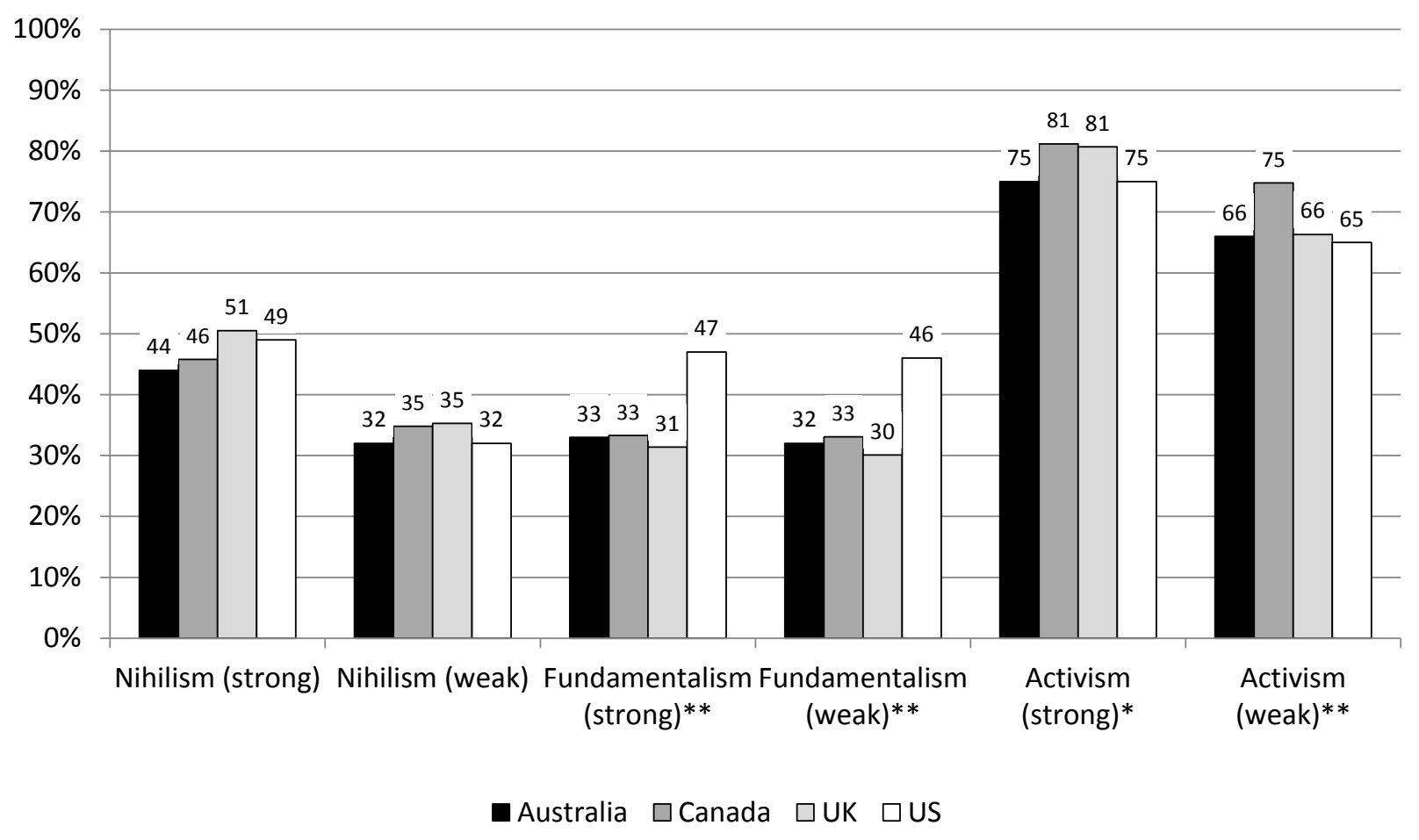

Fig. 6: Percentage of population agreeing or strongly agreeing with response to the future, by generation

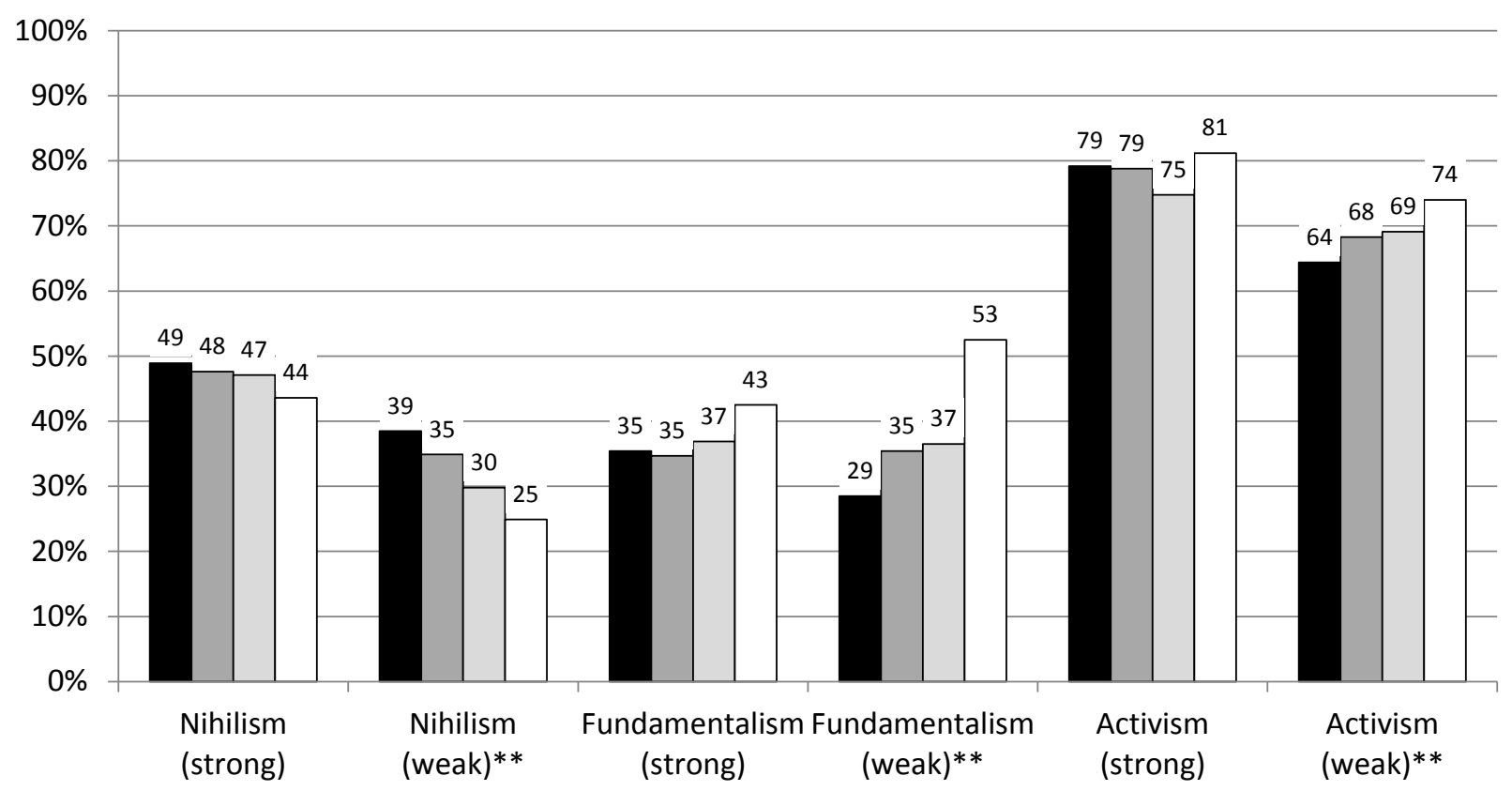

- Gen Y (1978-1993) $\square$ Gen X (1962-1977) $\square$ Baby boomers (1946-1961) $\square$ Pre-boomers (to 1945) 


\subsection{Global concerns, personal concerns and perceived stress}

Respondents were asked, in their everyday life, how concerned they felt about 23 global or societal issues. They were also asked, thinking about their own personal future, how concerned they were about 19 personal issues. The measurement items are detailed in Appendix 2 and the detailed findings will be the topic of a separate paper. Their significance to this paper lies in the positive correlations between perceived risks to humanity and average levels of concern about different issues.

Positive correlations with small to medium effect sizes were found between average level of concern about global issues and the belief that our existing way of life will end in the next 100 years $(\mathrm{r}=0.213, \mathrm{n}=2056, p=0.000)$; and between average level of concern for global issues and the belief that humans will be wiped out in the next 100 years $(\mathrm{r}=0.257, \mathrm{n}=2056, p=0.000)$. Small to medium positive effects were also found between average level of concern about personal issues and the belief that our existing way of life will end in the next 100 years $(r=0.108$, $\mathrm{n}=2073, p=0.000$ ); and between average level of concern for personal issues and the belief that humans will be wiped out in the next 100 years $(r=0.227, n=2073, p=0.000)$. Notably, a medium to large size positive correlation was found between average concern with global and personal issues ( $\mathrm{r}=0.486, \mathrm{n}=2056, \mathrm{p}=0.000$ ). Consistent with its significantly higher perceived risk to humanity than other countries (Fig. 1), analysis of variance revealed that the US also scored a significantly higher average level of concern across all global issues $[F(3,2052)=13.32$, $p=0.000]$.

Using the Perceived Stress Scale (Cohen et al., 1983), respondents were also asked about how often they thought or felt about a range of items in the past month to assess their level of personal stress (measurement items are detailed in Appendix 2). While borderline positive correlations were found between perceived personal stress and the belief that our existing way of life will end in the next 100 years $(\mathrm{r}=0.050, \mathrm{n}=2073, p=0.023)$, small to medium size positive correlations were found between perceived personal stress and the belief that humans will be wiped out in the next 100 years $(\mathrm{r}=0.151, \mathrm{n}=2073, p=0.000)$. Small positive correlations were found between perceived personal stress and average level of concern about global issues ( $\mathrm{r}=0.102, \mathrm{n}=2056, p=0.000$ ), however medium to strong positive correlations were found between perceived personal stress and average level of concern about personal issues $(r=0.455$, $\mathrm{n}=2073, p=0.000)$.

\section{Discussion}

How people rate the risk of catastrophic futures for humanity and how they respond to these perceptions have an important bearing on how humanity confronts these threats. This study of four developed nations - the US, UK, Canada and Australia - found that over a half (54\%) of respondents rated the risk of our current way of life ending within a century at $50 \%$ or more; a quarter (24\%) rated the risk of humanity becoming extinct with a century at the same level. These are surprisingly high probabilities for such extreme historical events. However, they are consistent with other studies of public perceptions of the future, as discussed in the Introduction. 
Furthermore, the survey findings, taken together, make up an internally consistent and compelling story, as indicated by:

- The relatively high level of agreement with three pairs of "apocalyptic response” statements - nihilism, fundamentalism, and activism (with 78\% and 68\% endorsing strong and weak activism, respectively).

- Increased agreement with nihilist and fundamentalist responses to the future amongst those who perceive a greater risk to humanity.

- The positive correlations between perceived risk to humanity and levels of concern over global and personal issues, and levels of perceived personal stress.

- The differentiating characteristics of the US, with its significantly higher proportion of people perceiving serious risk to humanity, greater agreement with fundamentalist responses, and greater concern over world issues.

- The consistency of findings (significant differences notwithstanding) across countries, and age, sex and education groupings (given the issues transcend common demographic differences).

That there was not the same strong and consistent association between perceived future risks and activist responses as there was with the nihilist and fundamentalist responses might reflect a degree of social desirability in responses, although it is not obvious that activism is desirable if people do not feel it is needed. It is more likely that people believe humanity needs to make profound changes even if they do not fear such extreme outcomes as the end of our way of life and human extinction. Nihilism and fundamentalism, on the other hand, are more clearly “apocalyptic” responses. Only 13 respondents ( $0.6 \%$ of the total sample) disagreed or strongly disagreed with all six response statements, suggesting they saw no need to change humanity's direction.

This study is about perceptions, not realities. Nor do the findings necessarily represent considered assessments of the specific risks. Rather, they are likely to be an expression of a more general uncertainty and fear about the future, a lack of faith in a future constructed around notions of material progress, economic growth and scientific and technological fixes to the challenges we face (Eckersley, 2007). This loss is important, yet barely registers in current debate and discussion. We have yet to understand its full implications.

The association between threat and response is not simple and linear; there is a dynamic relationship between future expectations, current social realities, and personal states of mind (Eckersley, 2005). As already noted in section 1, people can respond differently to perceptions of threat. Nihilism, fundamentalism and activism all offer benefits to our personal wellbeing and resilience: nihilism through a disengagement and distraction from frightening possibilities and prospects; fundamentalism through the conviction of righteousness and the promise of salvation; and activism through a unity of purpose and a belief in a cause. Yet only activism will allow us to deal constructively with global threats. 
At best, the high perception of risk and the strong endorsement of an activist response could drive a much greater effort to confront global threats. At worst, with a loss of hope, fear of a catastrophic future erodes people's faith in society, affecting their roles and responsibilities, and their relationship to social institutions, especially government (Eckersley, 2005; 2007). It can deny us a social ideal to believe in - something to convince us to subordinate our own individual interests to a higher social purpose. This drives us back on our own personal resources, reinforcing the self-focus and social alienation of other cultural qualities such as increasing materialism and individualism.

Bleak expectations of the humanity's future are likely to affect people's health and wellbeing beyond the direct impacts of specific disasters, as suggested in this study by the positive correlations between personal stress and perceived risks to humanity and global concerns, although the evidence is largely correlational and conjectural (Eckersley, 2005). For example, a sense of coherence - seeing the world as comprehensible, manageable and meaningful - is associated with wellbeing (Eckersley, 2005). People become more stressed and more vulnerable to stress-related illness if they feel they have little control over the causes, do not know how long the source of stress will last or how intense it will be, and interpret the stress as evidence that circumstances are worsening (Sapolsky, 2005). A positive (reinforcing) feedback can come into play: as our health and wellbeing, and our morale and vitality, decline, it becomes less likely we will have the resolve and resilience to address the challenges we face (Eckersley, 2010).

There is a deeply mythic dimension to this situation. Humans have always been susceptible to apocalyptic visions, especially in times of rapid change; we have also needed utopian ideals to inspire us (Hicks, 2006). Our visions of the future are woven into the stories we create to make sense and meaning of our lives, to link us to a broader social or collective narrative. Historians and futurists have emphasized the importance of confidence and optimism to the health of civilizations and, conversely, the dangers of cynicism and disillusion (Eckersley, 2005).

\section{Conclusions}

There is growing scientific evidence that humanity faces serious risks of a catastrophic coalescence of environmental, social, economic and technological threats within the next 100 years. Despite increasing political action on specific issues like climate change, globally the scale of our response falls far short of matching the magnitude of the challenges.

Closing this gap requires a deeper understanding of how people perceive the risks and how they might respond. Relatively little research has been done on the extent to which we see civilization, and even humanity itself, as endangered. This study has found that people in four developed nations rate this risk surprisingly high, especially given what is at stake.

The topic of this paper is largely neglected and underestimated outside futures studies. Economics and political science focus on the socio-economic and socio-political dimensions of the near future; environmental sciences focus on biophysical impacts; and health research focuses on individuals and their personal situation. The psychosocial dynamics of the far future warrant more consideration in scientific research and political debate. 


\section{Appendix 1. Sample description}

Actual numbers of participants are indicated in standard font, percentage values are indicated in parentheses. Row totals are indicted in italics. See Table A1.

Table A1: Sample characteristics

\begin{tabular}{|c|c|c|c|c|c|}
\hline & Australia & Canada & UK & US & Total \\
\hline Sample size & 516 & 520 & 519 & 518 & 2073 \\
\hline \multicolumn{6}{|l|}{ Sex } \\
\hline Male & $247(48)$ & $251(48)$ & $249(48)$ & $251(48)$ & $998(48)$ \\
\hline Female & $269(52)$ & $269(52)$ & $270(52)$ & $267(52)$ & $1075(52)$ \\
\hline \multicolumn{6}{|l|}{ Age } \\
\hline $18-24$ & $65(13)$ & $66(13)$ & $60(12)$ & $67(13)$ & $258(12)$ \\
\hline $25-34$ & $82(16)$ & $84(16)$ & $95(18)$ & $91(18)$ & $352(17)$ \\
\hline $35-44$ & $104(20)$ & $102(20)$ & $104(20)$ & $94(18)$ & $404(20)$ \\
\hline $45-54$ & $97(19)$ & $106(20)$ & $87(17)$ & $99(19)$ & $389(19)$ \\
\hline $55-64$ & $100(19)$ & $112(22)$ & $111(21)$ & $103(20)$ & $426(21)$ \\
\hline $65+$ & $68(13)$ & $50(10)$ & $62(12)$ & $64(12)$ & $244(12)$ \\
\hline \multicolumn{6}{|l|}{ Education/employment } \\
\hline \multicolumn{6}{|l|}{ Highest education level } \\
\hline No formal education & $1(0)$ & $4(1)$ & $4(1)$ & $10(2)$ & $19(1)$ \\
\hline Primary school & $12(2)$ & $11(2)$ & $3(1)$ & $46(9)$ & $72(4)$ \\
\hline Secondary school & $168(33)$ & $171(33)$ & $180(35)$ & $131(25)$ & $650(31)$ \\
\hline $\begin{array}{l}\text { Technical/vocational training or } \\
\text { apprenticeship }\end{array}$ & $153(30)$ & $145(28)$ & $144(28)$ & $127(25)$ & $569(28)$ \\
\hline University, undergraduate degree & $115(22)$ & $142(27)$ & $134(26)$ & $132(26)$ & $523(25)$ \\
\hline University, postgraduate degree & $67(13)$ & $47(9)$ & $54(10)$ & $72(14)$ & $240(12)$ \\
\hline \multicolumn{6}{|l|}{ Employment status } \\
\hline Working full-time & $163(32)$ & $202(39)$ & $225(43)$ & $172(33)$ & $762(37)$ \\
\hline Working part-time or casually & $105(20)$ & 75 (14) & $83(16)$ & $68(13)$ & $331(16)$ \\
\hline Unemployed but looking for work & $31(6)$ & $60(12)$ & $30(6)$ & $62(12)$ & $183(9)$ \\
\hline Homemaker & $62(12)$ & $50(10)$ & $47(9)$ & $66(13)$ & $225(11)$ \\
\hline Retired & $100(19)$ & $80(15)$ & $93(18)$ & $96(19)$ & $369(18)$ \\
\hline Student & $33(6)$ & $35(7)$ & $21(4)$ & $30(6)$ & $119(6)$ \\
\hline Other & $22(4)$ & $18(4)$ & $20(4)$ & $24(5)$ & $84(4)$ \\
\hline \multicolumn{6}{|c|}{ Employment position (\% figures are a proportion of those full-time, part-time or casually employed, $n=1093$ ) } \\
\hline Executive/top management & $13(5)$ & $19(7)$ & $19(6)$ & $37(15)$ & $88(8)$ \\
\hline Middle management & $56(21)$ & $38(14)$ & $49(16)$ & $45(19)$ & $188(17)$ \\
\hline Supervisory & $28(10)$ & $33(12)$ & $53(17)$ & $27(11)$ & $141(13)$ \\
\hline Administrative/clerical & $77(29)$ & $59(21)$ & $75(24)$ & $35(15)$ & $246(23)$ \\
\hline Technical & $42(16)$ & $53(19)$ & $39(13)$ & $32(13)$ & $166(15)$ \\
\hline Other & $52(19)$ & $75(27)$ & $73(24)$ & $64(27)$ & $264(24)$ \\
\hline \multicolumn{6}{|l|}{ Relationship/family } \\
\hline \multicolumn{6}{|l|}{ Relationship status } \\
\hline Not currently in a relationship & $158(31)$ & $174(34)$ & $162(31)$ & $166(32)$ & $660(32)$ \\
\hline Married & $255(49)$ & $223(43)$ & $225(43)$ & $256(49)$ & $959(46)$ \\
\hline
\end{tabular}




\begin{tabular}{|l|c|c|c|c|c|}
\hline Living with a partner (opposite sex) & $65(13)$ & $71(14)$ & $84(16)$ & $49(10)$ & $269(13)$ \\
\hline $\begin{array}{l}\text { Living with a partner (same sex) } \\
\begin{array}{l}\text { In a relationship (opposite sex), not living } \\
\text { together }\end{array}\end{array}$ & $43(1)$ & $10(2)$ & $11(2)$ & $4(1)$ & $29(1)$ \\
\hline $\begin{array}{l}\text { In a relationship (same sex), not living } \\
\text { together }\end{array}$ & $1(0)$ & $5(1)$ & $3(1)$ & $1(0)$ & $10(1)$ \\
$\begin{array}{l}\text { Children } \\
\text { Yes }\end{array}$ & $318(62)$ & $286(55)$ & $306(59)$ & $286(55)$ & $1196(58)$ \\
\hline No & $198(38)$ & $234(45)$ & $213(41)$ & $232(45)$ & $877(42)$ \\
\hline
\end{tabular}

\section{Appendix 2. Measures}

\section{Probability of threats to humanity}

In your opinion, how likely is it that our existing way of life will end in the next 100 years?

\begin{tabular}{|c|c|c|c|c|c|c|c|c|c|c|}
\hline 0 & 1 & 2 & 3 & 4 & 5 & 6 & 7 & 8 & 9 & 10 \\
\hline $\begin{array}{l}\text { No chance, } \\
\text { almost } \\
\text { no chance } \\
(1 \text { in } 100)\end{array}$ & $\begin{array}{c}\text { Very } \\
\text { slight } \\
\text { possibility } \\
(1 \text { in 10) }\end{array}$ & $\begin{array}{c}\text { Slight } \\
\text { possibility } \\
\text { (2 in 10) }\end{array}$ & $\begin{array}{c}\text { Some } \\
\text { possibility } \\
\text { (3 in 10) }\end{array}$ & $\begin{array}{c}\text { Fair } \\
\text { possibility } \\
(4 \text { in 10) }\end{array}$ & $\begin{array}{c}\text { Fairly } \\
\text { good } \\
\text { possibility } \\
\text { (5 in 10) }\end{array}$ & $\begin{array}{c}\text { Good } \\
\text { possibility } \\
\text { (6 in 10) }\end{array}$ & $\begin{array}{c}\text { Probable } \\
\text { (7 in 10) }\end{array}$ & $\begin{array}{c}\text { Very } \\
\text { probable } \\
(8 \text { in 10) }\end{array}$ & $\begin{array}{c}\text { Almost } \\
\text { sure } \\
(9 \text { in 10) }\end{array}$ & $\begin{array}{c}\text { Certain, } \\
\text { practically } \\
\text { certain } \\
(99 \text { in } 100)\end{array}$ \\
\hline
\end{tabular}

In your opinion, how likely is it that humans will be wiped out in the next 100 years?

\begin{tabular}{|c|c|c|c|c|c|c|c|c|c|c|}
\hline 0 & 1 & 2 & 3 & 4 & 5 & 6 & 7 & 8 & 9 & 10 \\
\hline $\begin{array}{l}\text { No chance, } \\
\text { almost } \\
\text { no chance } \\
(1 \text { in } 100)\end{array}$ & $\begin{array}{c}\text { Very } \\
\text { slight } \\
\text { possibility } \\
(1 \text { in 10) }\end{array}$ & $\begin{array}{c}\text { Slight } \\
\text { possibility } \\
(2 \text { in 10) }\end{array}$ & $\begin{array}{c}\text { Some } \\
\text { possibility } \\
(3 \text { in 10) }\end{array}$ & $\begin{array}{c}\text { Fair } \\
\text { possibility } \\
(4 \text { in 10) }\end{array}$ & $\begin{array}{c}\text { Fairly } \\
\text { good } \\
\text { possibility } \\
(5 \text { in 10) }\end{array}$ & $\begin{array}{c}\text { Good } \\
\text { possibility } \\
\text { (6 in 10) }\end{array}$ & $\begin{array}{c}\text { Probable } \\
\text { (7 in 10) }\end{array}$ & $\begin{array}{c}\text { Very } \\
\text { probable } \\
(8 \text { in 10) }\end{array}$ & $\begin{array}{c}\text { Almost } \\
\text { sure } \\
(9 \text { in 10) }\end{array}$ & $\begin{array}{c}\text { Certain, } \\
\text { practically } \\
\text { certain } \\
(99 \text { in } 100)\end{array}$ \\
\hline
\end{tabular}

Beliefs about, and response to, the future (Eckersley, 2008)

Thinking about global events and the future of the world, please indicate how much you agree or disagree with the following statements.

\begin{tabular}{|c|c|c|c|c|c|}
\hline & $\begin{array}{l}\text { Strongly } \\
\text { disagree }\end{array}$ & Disagree & $\begin{array}{c}\text { Neither } \\
\text { agree nor } \\
\text { disagree }\end{array}$ & Agree & $\begin{array}{c}\text { Strongly } \\
\text { Agree }\end{array}$ \\
\hline $\begin{array}{l}\text { The world's future looks grim so we have to } \\
\text { focus on looking after ourselves and those we } \\
\text { love. [strong nihilism] }\end{array}$ & 0 & 0 & 0 & 0 & 0 \\
\hline $\begin{array}{l}\text { We should enjoy the life we have now, and not } \\
\text { worry about what might happen to the world in } \\
\text { the future. [weak nihilism] }\end{array}$ & 0 & 0 & 0 & 0 & 0 \\
\hline $\begin{array}{l}\text { We are facing a final conflict between good } \\
\text { and evil in the world. [strong fundamentalism] }\end{array}$ & 0 & 0 & 0 & 0 & 0 \\
\hline $\begin{array}{l}\text { We need to return to traditional religious } \\
\text { teachings and values to solve global problems } \\
\text { and challenges. [weak fundamentalism] }\end{array}$ & 0 & O & 0 & 0 & 0 \\
\hline $\begin{array}{l}\text { We need to transform our worldview and way } \\
\text { of life if we are to create a better future for the }\end{array}$ & 0 & 0 & 0 & 0 & 0 \\
\hline
\end{tabular}




\begin{tabular}{|c|c|c|c|c|c|}
\hline world. [strong activism] & & & & & \\
\hline $\begin{array}{l}\text { Hope for the future rests with a growing global } \\
\text { movement that wants to create a more } \\
\text { peaceful, fair and sustainable world. [weak } \\
\text { activism] }\end{array}$ & O & $\mathrm{O}$ & $\mathrm{O}$ & O & O \\
\hline
\end{tabular}

\section{Global concerns}

In your everyday life, how concerned do you feel about the following issues?

\begin{tabular}{|c|c|c|c|c|c|}
\hline & $\begin{array}{l}\text { I never } \\
\text { think } \\
\text { about it }\end{array}$ & $\begin{array}{c}\text { I think } \\
\text { about it but } \\
\text { I'm not at } \\
\text { all } \\
\text { concerned }\end{array}$ & $\begin{array}{l}\text { I'm a little } \\
\text { bit } \\
\text { concerned }\end{array}$ & $\begin{array}{l}\text { I'm } \\
\text { moderately } \\
\text { concerned }\end{array}$ & $\begin{array}{c}\text { I'm } \\
\text { seriously } \\
\text { concerned }\end{array}$ \\
\hline Global warming/climate change & $\mathrm{O}$ & $\mathrm{O}$ & $\mathrm{O}$ & $\mathrm{O}$ & $\mathrm{O}$ \\
\hline Resources such as oil running out & $\mathrm{O}$ & $\mathrm{O}$ & $\mathrm{O}$ & $\mathrm{O}$ & $\mathrm{O}$ \\
\hline $\begin{array}{l}\text { Natural disasters (e.g. floods, } \\
\text { tsunamis, hurricanes, earthquakes, } \\
\text { wildfires etc.) }\end{array}$ & O & O & O & O & O \\
\hline Lack of fresh water & $\mathrm{O}$ & $\mathrm{O}$ & $\mathrm{O}$ & $\mathrm{O}$ & $\mathrm{O}$ \\
\hline Pollution of air and water & $\mathrm{O}$ & $\mathrm{O}$ & $\mathrm{O}$ & $\mathrm{O}$ & $\mathrm{O}$ \\
\hline Corruption of politicians/officials & $\mathrm{O}$ & $\mathrm{O}$ & $\mathrm{O}$ & $\mathrm{O}$ & $\mathrm{O}$ \\
\hline The state of world politics & $\mathrm{O}$ & $\mathrm{O}$ & $\mathrm{O}$ & $\mathrm{O}$ & $\mathrm{O}$ \\
\hline The state of politics in my country & $\mathrm{O}$ & $\mathrm{O}$ & $\mathrm{O}$ & $\mathrm{O}$ & $\mathrm{O}$ \\
\hline Wars/weapons of mass destruction & O & O & O & O & O \\
\hline Terrorist attacks & 0 & 0 & 0 & $\mathrm{O}$ & $\mathrm{O}$ \\
\hline Crime and violence in everyday life & $\mathrm{O}$ & $\mathrm{O}$ & $\mathrm{O}$ & $\mathrm{O}$ & $\mathrm{O}$ \\
\hline Collapse of global financial systems & $\mathrm{O}$ & $\mathrm{O}$ & $\mathrm{O}$ & $\mathrm{O}$ & $\mathrm{O}$ \\
\hline Long-term economic depression & $\mathrm{O}$ & $\mathrm{O}$ & $\mathrm{O}$ & $\mathrm{O}$ & $\mathrm{O}$ \\
\hline $\begin{array}{l}\text { Technological changes (e.g. internet, } \\
\text { social networking) }\end{array}$ & O & O & O & O & O \\
\hline Online terrorism/warfare & 0 & 0 & $\mathrm{O}$ & $\mathrm{O}$ & $\mathrm{O}$ \\
\hline Online bullying & $\mathrm{O}$ & O & $\mathrm{O}$ & $\mathrm{O}$ & $\mathrm{O}$ \\
\hline Increasing lack of privacy & $\mathrm{O}$ & $\mathrm{O}$ & $\mathrm{O}$ & $\mathrm{O}$ & $\mathrm{O}$ \\
\hline Famine and poverty & $\mathrm{O}$ & $\mathrm{O}$ & $\mathrm{O}$ & $\mathrm{O}$ & $\mathrm{O}$ \\
\hline $\begin{array}{l}\text { Existing incurable diseases (e.g. } \\
\text { cancer) }\end{array}$ & O & O & O & O & O \\
\hline New types of incurable diseases & $\mathrm{O}$ & $\mathrm{O}$ & $\mathrm{O}$ & $\mathrm{O}$ & $\mathrm{O}$ \\
\hline $\begin{array}{l}\text { Worldwide } \\
\text { epidemics/pandemics/outbreaks }\end{array}$ & $\mathrm{O}$ & $\mathrm{O}$ & O & $\mathrm{O}$ & O \\
\hline $\begin{array}{l}\text { How fast society is changing (e.g. } \\
\text { marriage/divorce, birth rates, } \\
\text { household changes) }\end{array}$ & O & O & O & O & O \\
\hline Breakdown of society's moral values & $\mathrm{O}$ & $\mathrm{O}$ & $\mathrm{O}$ & $\mathrm{O}$ & $\mathrm{O}$ \\
\hline
\end{tabular}

Note: The "I never think about it" option was made available to participants after pre-testing revealed that some global issues had not personally affected some people in the past and 
therefore the individual had never thought about them before. These answers were excluded from calculations of mean scores of concern.

Personal concerns

Thinking about your own personal future, how concerned are you about each of the following?

\begin{tabular}{|c|c|c|c|c|}
\hline & $\begin{array}{l}\text { Not at all } \\
\text { concerned }\end{array}$ & $\begin{array}{l}\text { A little bit } \\
\text { concerned }\end{array}$ & $\begin{array}{c}\text { Moderately } \\
\text { concerned }\end{array}$ & $\begin{array}{c}\text { Seriously } \\
\text { concerned }\end{array}$ \\
\hline Family relationships & $\mathrm{O}$ & $\mathrm{O}$ & $\mathrm{O}$ & $\mathrm{O}$ \\
\hline Wellbeing of family members & 0 & 0 & $\mathrm{O}$ & 0 \\
\hline Friendships & $\mathrm{O}$ & $\mathrm{O}$ & $\mathrm{O}$ & $\mathrm{O}$ \\
\hline Physical health & $\mathrm{O}$ & $\mathrm{O}$ & $\mathrm{O}$ & $\mathrm{O}$ \\
\hline Mental/emotional health & $\mathrm{O}$ & $\mathrm{O}$ & $\mathrm{O}$ & $\mathrm{O}$ \\
\hline Death & $\mathrm{O}$ & $\mathrm{O}$ & $\mathrm{O}$ & $\mathrm{O}$ \\
\hline Serious accidents & $\mathrm{O}$ & $\mathrm{O}$ & $\mathrm{O}$ & $\mathrm{O}$ \\
\hline Old age & $\mathrm{O}$ & $\mathrm{O}$ & $\mathrm{O}$ & $\mathrm{O}$ \\
\hline Finding a job & $\mathrm{O}$ & $\mathrm{O}$ & $\mathrm{O}$ & $\mathrm{O}$ \\
\hline Finding a job I like & $\mathrm{O}$ & $\mathrm{O}$ & $\mathrm{O}$ & $\mathrm{O}$ \\
\hline Retirement & $\mathrm{O}$ & $\mathrm{O}$ & $\mathrm{O}$ & $\mathrm{O}$ \\
\hline Education & $\mathrm{O}$ & $\mathrm{O}$ & $\mathrm{O}$ & $\mathrm{O}$ \\
\hline Financial security & $\mathrm{O}$ & $\mathrm{O}$ & $\mathrm{O}$ & $\mathrm{O}$ \\
\hline Superannuation & $\mathrm{O}$ & $\mathrm{O}$ & $\mathrm{O}$ & $\mathrm{O}$ \\
\hline Cost of living & $\mathrm{O}$ & $\mathrm{O}$ & $\mathrm{O}$ & $\mathrm{O}$ \\
\hline Failure/disappointment & $\mathrm{O}$ & $\mathrm{O}$ & $\mathrm{O}$ & $\mathrm{O}$ \\
\hline Making wrong decisions & $\mathrm{O}$ & $\mathrm{O}$ & $\mathrm{O}$ & $\mathrm{O}$ \\
\hline Loneliness & $\mathrm{O}$ & $\mathrm{O}$ & $\mathrm{O}$ & $\mathrm{O}$ \\
\hline Emptiness & 0 & 0 & 0 & 0 \\
\hline
\end{tabular}

Note: A “never think about it” option was not included for personal concerns as pre-testing revealed that the personal issues listed held at least some relevance for all individuals.

Perceived stress (Cohen et al., 1983)

The following questions ask you about your feelings and thoughts during the last month. In each case, you will be asked to indicate how often you felt or thought a certain way. Although some of the questions are similar, there are differences between them and you should treat each one as a separate question. The best approach is to answer each question fairly quickly. That is, do not try to count up the number of times you felt a particular way, but rather indicate the alternative that seems like a reasonable estimate. Please read each statement carefully, and then select the appropriate answer.

\begin{tabular}{|c|c|c|c|c|c|}
\hline In the last month, how often have you... & Never & $\begin{array}{c}\text { Almost } \\
\text { never }\end{array}$ & Sometimes & $\begin{array}{c}\text { Fairly } \\
\text { often }\end{array}$ & $\begin{array}{l}\text { Very } \\
\text { often }\end{array}$ \\
\hline $\begin{array}{l}\text {...been upset because of something that } \\
\text { happened? }\end{array}$ & O & O & O & O & O \\
\hline $\begin{array}{l}\text {...felt unable to control the important things in } \\
\text { your life? }\end{array}$ & $\mathrm{O}$ & $\mathrm{O}$ & O & O & $\mathrm{O}$ \\
\hline
\end{tabular}




\begin{tabular}{|c|c|c|c|c|c|}
\hline ...felt nervous and stressed? & $\mathrm{O}$ & $\mathrm{O}$ & $\mathrm{O}$ & $\mathrm{O}$ & $\mathrm{O}$ \\
\hline $\begin{array}{l}\text {...dealt successfully with irritating life } \\
\text { hassles? (R) }\end{array}$ & O & O & O & O & $\mathrm{O}$ \\
\hline $\begin{array}{l}\text {...felt that you were effectively coping with } \\
\text { important changes that were occurring in your } \\
\text { life? (R) }\end{array}$ & O & O & O & O & O \\
\hline $\begin{array}{l}\text {...felt confident about your ability to handle } \\
\text { your personal problems? (R) }\end{array}$ & O & O & O & O & O \\
\hline ...felt that things were going your way? (R) & $\mathrm{O}$ & $\mathrm{O}$ & $\mathrm{O}$ & $\mathrm{O}$ & $\mathrm{O}$ \\
\hline $\begin{array}{l}\text {...found that you could not cope with all the } \\
\text { things that you had to do? }\end{array}$ & O & O & $\mathrm{O}$ & O & O \\
\hline $\begin{array}{l}\text {...been able to control irritations in your life? } \\
\text { (R) }\end{array}$ & O & O & $\mathrm{O}$ & O & $\mathrm{O}$ \\
\hline ...felt that you were on top of things? (R) & $\mathrm{O}$ & $\mathrm{O}$ & $\mathrm{O}$ & $\mathrm{O}$ & $\mathrm{O}$ \\
\hline $\begin{array}{l}\text {...been angered because of things that } \\
\text { happened that were outside of your control? }\end{array}$ & O & O & O & O & O \\
\hline $\begin{array}{l}\text {...found yourself thinking about things that } \\
\text { you have to accomplish? }\end{array}$ & 0 & 0 & 0 & 0 & 0 \\
\hline $\begin{array}{l}\text {...been able to control the way you spend your } \\
\text { time? (R) }\end{array}$ & 0 & 0 & 0 & 0 & 0 \\
\hline $\begin{array}{l}\text {...felt difficulties were piling up so high that } \\
\text { you could not overcome them? }\end{array}$ & 0 & 0 & 0 & 0 & 0 \\
\hline
\end{tabular}

Items with reverse scoring are indicated with an $(R)$. Scores for all were summed to produce an overall score of perceived stress for each individual (range 0-56).

\section{Appendix 3. Detailed tables}

See Tables A2 and A3.

Table A2: Beliefs about and behavioral response to the future by country

\begin{tabular}{|c|c|c|c|c|c|c|c|}
\hline \multirow{2}{*}{\multicolumn{2}{|c|}{ Response }} & \multicolumn{4}{|c|}{ Country (\%) } & \multirow{2}{*}{$\begin{array}{c}\text { Total } \\
\text { sample } \\
(\%) \\
\end{array}$} & \multirow[b]{2}{*}{$\begin{array}{c}p- \\
\text { value }\end{array}$} \\
\hline & & $\begin{array}{c}\text { Australia } \\
(n=516)\end{array}$ & $\begin{array}{l}\text { Canada } \\
(\mathrm{n}=520)\end{array}$ & $\begin{array}{c}\text { UK } \\
(n=519)\end{array}$ & $\begin{array}{c}\text { USA } \\
(n=518)\end{array}$ & & \\
\hline \multirow{3}{*}{$\begin{array}{l}\text { Nihilism } \\
\text { (strong) }\end{array}$} & Agree & 44.4 & 45.8 & 50.5 & 49.2 & 47.5 & \multirow[t]{3}{*}{.508} \\
\hline & Neither & 28.1 & 27.7 & 25.8 & 25.7 & 26.8 & \\
\hline & Disagree & 27.5 & 26.5 & 23.7 & 25.1 & 25.7 & \\
\hline \multirow{3}{*}{$\begin{array}{l}\text { Nihilism } \\
\text { (weak) }\end{array}$} & Agree & 32.4 & 34.8 & 35.3 & 31.5 & 33.5 & \multirow[t]{3}{*}{.123} \\
\hline & Neither & 23.6 & 18.7 & 21.0 & 18.0 & 20.3 & \\
\hline & Disagree & 44.0 & 46.5 & 43.7 & 50.6 & 46.2 & \\
\hline \multirow{3}{*}{$\begin{array}{l}\text { Fundamentalism } \\
\text { (strong) }\end{array}$} & Agree & 33.1 & 33.3 & 31.4 & 47.3 & 36.3 & \multirow[t]{3}{*}{.000} \\
\hline & Neither & 32.8 & 31.0 & 30.3 & 24.1 & 29.5 & \\
\hline & Disagree & 34.1 & 35.8 & 38.3 & 28.6 & 34.2 & \\
\hline \multirow{3}{*}{$\begin{array}{l}\text { Fundamentalism } \\
\text { (weak) }\end{array}$} & Agree & 32.2 & 33.1 & 30.1 & 45.6 & 35.2 & \multirow[t]{3}{*}{.000} \\
\hline & Neither & 26.6 & 26.7 & 30.1 & 26.8 & 27.5 & \\
\hline & Disagree & 41.3 & 40.2 & 39.9 & 27.6 & 37.2 & \\
\hline \multirow{3}{*}{$\begin{array}{l}\text { Activism } \\
\text { (strong) }\end{array}$} & Agree & 74.8 & 81.2 & 80.7 & 74.7 & 77.9 & \multirow[t]{3}{*}{.023} \\
\hline & Neither & 19.8 & 14.0 & 14.3 & 17.6 & 16.4 & \\
\hline & Disagree & 5.4 & 4.8 & 5.0 & 7.7 & 5.7 & \\
\hline
\end{tabular}




\begin{tabular}{|l|l|c|c|c|c|c|c|}
\hline \multirow{2}{*}{$\begin{array}{l}\text { Activism } \\
\text { (weak) }\end{array}$} & Agree & $\mathbf{6 6 . 1}$ & $\mathbf{7 4 . 8}$ & $\mathbf{6 6 . 3}$ & $\mathbf{6 4 . 5}$ & $\mathbf{6 7 . 9}$ & $\mathbf{0 0 1}$ \\
\cline { 2 - 7 } & Neither & 25 & $\mathbf{1 8 . 3}$ & $\mathbf{2 5 . 8}$ & 23.2 & $\mathbf{2 3 . 1}$ & \\
\cline { 2 - 7 } & Disagree & $\mathbf{8 . 9}$ & $\mathbf{6 . 9}$ & $\mathbf{7 . 9}$ & $\mathbf{1 2 . 4}$ & $\mathbf{9 . 0}$ & \\
\hline
\end{tabular}

Table 3: Beliefs about and behavioral response to the future by generation

\begin{tabular}{|c|c|c|c|c|c|c|c|}
\hline \multirow{2}{*}{\multicolumn{2}{|c|}{ Response }} & \multicolumn{4}{|c|}{ Generation (\%) } & \multirow[b]{2}{*}{$\begin{array}{c}\text { Total } \\
\text { sample } \\
(\%)\end{array}$} & \multirow[b]{2}{*}{$\begin{array}{c}p- \\
\text { value }\end{array}$} \\
\hline & & $\begin{array}{c}\text { Gen Y } \\
(n=610)\end{array}$ & $\begin{array}{c}\text { Gen X } \\
(n=628)\end{array}$ & $\begin{array}{c}\text { Baby } \\
\text { boomers } \\
(\mathrm{n}=654)\end{array}$ & $\begin{array}{c}\text { Pre- } \\
\text { boomers } \\
(\mathbf{n}=181)\end{array}$ & & \\
\hline \multirow{3}{*}{$\begin{array}{l}\text { Nihilism } \\
\text { (strong) }\end{array}$} & Agree & 48.9 & 47.6 & 47.1 & 43.6 & 47.5 & \multirow[t]{3}{*}{.412} \\
\hline & Neither & 28.4 & 26.9 & 25.5 & 26.0 & 26.8 & \\
\hline & Disagree & 22.8 & 25.5 & 27.4 & 30.4 & 25.7 & \\
\hline \multirow{3}{*}{$\begin{array}{l}\text { Nihilism } \\
\text { (weak) }\end{array}$} & Agree & 38.5 & 34.9 & 29.8 & 24.9 & 33.5 & \multirow[t]{3}{*}{.000} \\
\hline & Neither & 22.1 & 21.3 & 19.1 & 14.9 & 20.3 & \\
\hline & Disagree & 39.3 & 43.8 & 51.1 & 60.2 & 46.2 & \\
\hline \multirow{3}{*}{$\begin{array}{l}\text { Fundamentalism } \\
\text { (strong) }\end{array}$} & Agree & 35.4 & 34.7 & 36.9 & 42.5 & 36.3 & \multirow[t]{3}{*}{.087} \\
\hline & Neither & 31.8 & 30.6 & 26.1 & 30.4 & 29.5 & \\
\hline & Disagree & 32.8 & 34.7 & 37.0 & 27.1 & 34.2 & \\
\hline \multirow{3}{*}{$\begin{array}{l}\text { Fundamentalism } \\
\text { (weak) }\end{array}$} & Agree & 28.5 & 35.4 & 36.5 & 52.5 & 35.2 & \multirow[t]{3}{*}{.000} \\
\hline & Neither & 28.4 & 28.3 & 26.8 & 24.9 & 27.5 & \\
\hline & Disagree & 43.1 & 36.3 & 36.7 & 22.7 & 37.2 & \\
\hline \multirow{3}{*}{$\begin{array}{l}\text { Activism } \\
\text { (strong) }\end{array}$} & Agree & 79.2 & 78.8 & 74.8 & 81.2 & 77.9 & \multirow[t]{3}{*}{.260} \\
\hline & Neither & 14.8 & 16.6 & 18.7 & 13.3 & 16.4 & \\
\hline & Disagree & 6.1 & 4.6 & 6.6 & 5.5 & 5.7 & \\
\hline \multirow{3}{*}{$\begin{array}{l}\text { Activism } \\
\text { (weak) }\end{array}$} & Agree & 64.4 & 68.3 & 69.1 & 74.0 & 67.9 & \multirow[t]{3}{*}{.002} \\
\hline & Neither & 25 & 18.3 & 25.8 & 23.2 & 23.1 & \\
\hline & Disagree & 8.9 & 6.9 & 7.9 & 12.4 & 9.0 & \\
\hline
\end{tabular}

\section{Acknowledgements}

This study was funded by the Institute for Innovation in Business and Social Research (IIBSoR) at the University of Wollongong Australia. The authors would like to thank Dr. Leonie Miller for her consultation and advice regarding the statistical analysis presented in this paper. The authors report no conflicts of interest.

\section{References}

Cohen, S., Kamarck, T. \& Mermelstein, R. (1983). A global measure of perceived stress. Journal of Health and Social Behaviour 24, 385-396.

Dator, J. (2009). The unholy trinity, plus one. Journal of Futures Studies 13, 33-48.

Eckersley, R. (2005). Well \& good: Morality, meaning and happiness, second ed. Melbourne: Text. 
Eckersley, R. (2007). What's wrong with the official future? In: G. Hassan (ed). After Blair: Politics after the New Labour decade (pp. 172-184). London: Lawrence and Wishart.

Eckersley, R, Cahill, H., Wierenga, A. \& Wyn, J. (2007). Generations in dialogue about the future: The hopes and fears of young Australians, Australia21 Ltd, Canberra. Melbourne: Australian Youth Research Centre.

Eckersley, R. (2008). Nihilism, fundamentalism, or activism: Three responses to fears of the Apocalypse, Futurist 42, 35-39.

Eckersley, R. (2010). Population health: a forgotten dimension of social resilience. In S. Cork (Ed). Resilience and transformation: Preparing Australia for uncertain futures (pp. 115120). Melbourne: CSIRO Publishing.

Eckersley, R. (2013). Subjective well-being: Telling only half the story, Social Indicators Research 112, 529-534.

Ehrlich, P. R. \& Ehrlich A. H. (2013). Can a collapse of global civilization be avoided? Proceedings of the Royal Society B, 280, 20122845.

Halal, W. \& Marien, M. (2011). Global megacrisis: A survey of four scenarios on a pessimismoptimism axis. Journal of Futures Studies 16, 65-84.

Hamilton, C. (2010). Requiem for a species: Why we resist the truth about climate change. London, NewYork: Earthscan.

Hicks, D.W. (2006). Lessons for the future: The missing dimension in education. Victoria, BC: Trafford Publishing.

Human extinction. (2009) Special issue, Futures 41.

Juster, F. (1996). Consumer buying intentions and purchase probability: An experiment in survey design. New York: Columbia University Press.

Lindfors, P., Solantaus, T. \& Rimpela, A. (2012). Fears for the future among Finnish adolescents in 1983-2007: From global concerns to ill health and loneliness. Journal of Adolescence 35, 991-999.

Sapolsky, R. (December, 2005). Sick of poverty. Scientific American.

The end. (September 2010). Special issue, Scientific American.

Tonn, B. \& MacGregor, D. (2009). Are we doomed? Editorial, Futures 41, 673-675.

Tonn, B. (2009). Beliefs about human extinction, Futures 41, 766-773. 